\title{
The perils of a second first language
}

English in Europe is a subject that ET has explored as fully as anything we cover. Issues include whether it will be the key language of the EU, how Anglicisms have been infiltrating other European languages, and how much ground the Germanic languages may be surrendering.

For some years I have been thinking about the 'Scotlandization' of North-western Europe. In the 17th and 18th centuries, the Scots language sagged under pressure from English, and today most Scots use a variable hybrid. The times, politics, traditions, and scale are different, but it seems to me that in Denmark, Norway, Sweden, and the Netherlands certain irreversible things are happening, such as the writing of academic papers in English, while more and more activities draw elements of English into the national language, or dictate a transfer straight to English for reasons of business or cost. As a Swedish taxi-driver once said to me, 'I read books in English because they're cheaper' (that is, than Swedish translations of the same books).

And now German, with its 100 million or so speakers. In the news we read about the bid by the German media giant Bertelsmann for Random House in the US, followed by a union between Daimler and Chrysler. An essential element in such moves is the willingness and the need for Germans to operate more and more in English, the essential language of business with Americans. In Business Week ('English Spoken Here - and Here, and Here...', 1 May 98), Stephen Baker reports on attending the world's largest technology trade show, CeBIT, in Hannover. It was, he said, just like being at Comdex in Las Vegas. Germans were even talking to Germans in English. Of one incident he says:

'It doesn't appear to bother them, or even strike them as odd, that a countryman would address [young women workers] in English. For how was he to know they were Germans? Instead of wasting time by asking, he simply cut to the chase in English.' Was the man in question asking for technical Microsoft-style information? Not at all. He was ordering snacks for some guests. Sounds just like Glasgow to me. Scots don't mind being addressed in English either - by and large.

Tom McArthur

The editorial policy of English Today is to provide a focus or forum for all sorts of news and opinion from around the world. The points of view of individual writers are as a consequence their own, and do not reflect the opinion of the editorial board. In addition, wherever feasible, ET generally leaves unchanged the orthography' (normally British or American) and the usage of individual contributors, although the editorial style of the journal itself is that of Cambridge University Press. 